\title{
Apolipoprotein E3 as a Risk Factor for Alzheimer's Disease Under Conditions of Nutritional Imbalance
}

\author{
Amy Chan and Thomas B. Shea* \\ Center for Cellular Neurobiology and Neurodegeneration Research, UMassLowell, Lowell, MA, USA
}

Accepted 22 February 2010

\begin{abstract}
The presence of one or more copies of the E4 allele of apolipoprotein E (ApoE) is strongly associated with of Alzheimer's disease (AD). The impact of E4 on neurodegeneration is potentiated by dietary oxidative challenge. Our prior studies in transgenic mice demonstrate that, in the face of dietary oxidative challenge, E3 does not provide any further protection than E4 or lack of murine ApoE for aggression, oxidative damage, presenilin-1 expression, and $\gamma$-secretase activity, and provides only partial reduction in phospho-tau levels. Extrapolation of these findings to the human condition leads us to hypothesize that the E3 allele may not provide sufficient neuroprotection under conditions of dietary compromise and/or oxidative challenge. Epidemiological evidence is consistent with this possibility. The E3 allele is approximately half as effective compared to E2 at buffering the impact of a single E4 allele. In addition, the risk of AD increases linearly for the genotypes E2/2, E2/3, and E3/3. It has been proposed that that clinical manifestation of $\mathrm{AD}$ may in some cases require the convergence of 2 or more risk factors. We hypothesize that the combined impact of dietary oxidative stress and either the ApoE3 or E4 genotype represents one such condition.
\end{abstract}

Keywords: Alzheimer's disease, apolipoprotein E, diet, nutritional deficiency, oxidative stresss

\section{APOE, OXIDATIVE DAMAGE, AND ALZHEIMER'S DISEASE}

A major risk factor for Alzheimer's disease (AD) is the presence of the $\mathrm{E} 4$ allele of apolipoprotein $\mathrm{E}$ (ApoE), which accounts for up to $50 \%$ of the cases of $\mathrm{AD}$ [1-5]. Considerable effort has been devoted to determining the nature and extent of risk imparted by ApoE4 and what might be done to lessen this risk [6]. Oxidative damage represents an early and perhaps pivotal factor contributing to age-related decline in cogni-

* Correspondence to: Thomas B. Shea, Center for Cellular Neurobiology and Neurodegeneration Research, UMassLowell, Lowell, Massachusetts 01854, USA. Tel.: +1 978934 2881; Fax: +1 978 934 3044; E-mail: Thomas_Shea@uml.edu. tive performance including that associated with AD [712]. Oxidative damage and ApoE4 are inter-related, as the extent of brain oxidative damage in $\mathrm{AD}$ is correlated with the presence of E4 [13-16]. ApoE mediates transport and clearance of lipids, including those subjected to oxidative damage. In doing so, ApoE prevents a cascade of neuronal oxidative damage by quenching downstream products of lipid oxidation, preventing secondary glutamate excitotoxicity and sequestering oxidative metals such as iron $[4,17,18,20]$. However, ApoE4 is thought to be less effective at this latter function [21].

While over 20 other genes are suspected of being related to $\mathrm{AD}$ [22], deficiency in ApoE function has a particularly far-reaching impact in that it not only impairs overall brain metabolism and may impair compensato- 
Table 1

Impact of dietary challenge on behavioral and biochemical parameters associated with AD in transgenic mice of various ApoE genotypes. Mice were maintained for 1 month on a complete diet or a deficient diet lacking folate and vitamin E and containing $500 \mathrm{mg}$ iron/kg total diet weight, after which various groups were subjected to Y maze to quantify cognitive performance [79], the intruder-based aggression test [51], following which they were sacrificed and cortical-hippocampal homogenates were assayed for oxidative damage (by TBARs assay), PS-1 expression (by RT-PCR), $\gamma$-secretase activity (by fluorescence spectophotometry), and A $\beta$ and phospho-tau levels by immunoblot analyses [52,66,86,87]

\begin{tabular}{|c|c|c|c|c|c|c|c|}
\hline \multirow[t]{2}{*}{$\mathrm{ApoE}^{1}$} & \multicolumn{2}{|c|}{ Behavioral parameters $^{2}$} & \multicolumn{5}{|c|}{ Biochemical parameters $^{3}$} \\
\hline & Cognition & Aggression & Oxidative damage & PS-1 expression & $\gamma-$ secretase activity & $\mathrm{A} \beta$ levels & Phospho-tau levels \\
\hline E4 & $-19 \pm 6 \%^{4}$ & $86 \pm 33 \%{ }^{4}$ & $1.5 \pm 0.3^{4}$ & $1.4 \pm 0.1^{4}$ & $2.2 \pm 0.2^{4}$ & $4.5 \pm 2.1^{4}$ & $1.7 \pm 0.1^{4}$ \\
\hline E3 & $-6 \pm 8 \%$ & $71 \pm 33 \%{ }^{4}$ & $1.4 \pm 0.2^{4}$ & $1.3 \pm 0.1^{4}$ & $2.1 \pm 0.2^{4}$ & $1.1 \pm 2.1$ & $1.3 \pm 0.2$ \\
\hline E2 & $-8 \pm 2 \%$ & $0 \%$ & nd & $1.3 \pm 0.1^{4}$ & $1.1 \pm 0.5^{4}$ & $0.5 \pm 0.5$ & nd \\
\hline$-/-$ & $-13 \pm 4 \%^{4}$ & $0 \%$ & $2.1 \pm 0.1^{4}$ & $1.5 \pm 0.2^{4}$ & $2.0 \pm 0.1^{4}$ & $2.8 \pm 0.6^{4}$ & $2.6 \pm 0.5^{4}$ \\
\hline$+/-$ & $4 \pm 5 \%$ & $0 \%$ & $1.6 \pm 0.1^{4}$ & nd & nd & nd & nd \\
\hline
\end{tabular}

${ }^{1} \mathrm{E} 2, \mathrm{E} 3$, and E4 refer to mice lacking murine ApoE and homozygously expressing the respective human alleles; +/- and -/- refer to murine ApoE copy number.

${ }^{2}$ Expressed as percent change versus normal (ApoE+/+) mice on a complete diet.

${ }^{3}$ Expressed as fold change versus ApoE $+/+$ mice on a complete diet; nd: not determined.

${ }^{4}$ Indicates value differs statistically $(\mathrm{p}<0.05)$ from value obtained for ApoE $+/+$ mice.

ry regeneration $[23,24]$, but also potentiates several additional risk factors. Deficiency in ApoE function not only impairs clearance of amyloid- $\beta(\mathrm{A} \beta)$, but it also augments the deleterious consequences of presenilin-1 (PS-1) overexpression and increases $\gamma$-secretase activity, both of which increase $A \beta$ generation [25,27-32]. It is of interest that these three AD risk factors - impaired ApoE function, PS- 1 overexpression, and increased $\mathrm{A} \beta$ levels - are inter-related and have in common the promotion of increased neuronal oxidative damage [11, 14-16,33-41].

Transgenic mice in which one or both copies of the single murine ApoE allele has been ablated (ApoE+/or -/-) have been useful models for studying the impact of ApoE on age-related cognitive decline and AD. More appropriate models include mice in which the murine allele has been replaced with human alleles. Like individuals with $\mathrm{AD}$, ApoE-/- mice and mice expressing human E4 ("E4 mice") display increased oxidative damage in brain tissue [15].

\section{NUTRITIONAL DEFICIENCY POTENTIATES THE IMPACT OF DEFICIENCY IN APOE FUNCTION IN MOUSE MODELS}

Nutritional compromise often accompanies aging and can contribute to neurological deficiencies by multiple mechanisms including increased oxidative stress $[8,33,42,47]$. Our laboratory has for years studied the impact of nutritional compromise leading to oxidative challenge. Many of our studies have compared the impact of nutritional compromise on normal (i.e., ApoE+/+) mice versus -/- mice, and/or mice expressing human ApoE alleles, since pioneering studies demonstrated that antioxidant supplementation can alleviate some of the oxidative damage in E4 mice [14, 40]. Studies from our laboratory and others demonstrate that folate deficiency potentiates several AD genetic risk factors, including increasing homocysteine, which potentiates $\mathrm{A} \beta$ neurotoxicity [47-50]. The decline in S-adenosyl methionine (SAM) that accompanies folate deficiency fosters PS-1 overexpression, increases activity of $\beta$ - and $\gamma$-secretases, increases levels of $\mathrm{A} \beta$ [51-54], and compromises glutathione usage, which in turn increases oxidative stress and potentiates the impact of deficiency in ApoE function $[3,55]$.

In these studies, we maintained mice of various ApoE genotype on a complete, vitamin-enriched diet, or instead on a "challenge diet", which lacked folate and vitamin $\mathrm{E}$, and instead contained a high level of iron to promote oxidative stress, and monitored mice for behavioral and biochemical parameters associated with AD (Table 1). Dietary challenge induced or potentiated the deleterious impact of lack of murine ApoE or expression of E4 on many of these parameters. Notably, however, dietary challenge also exerted a deleterious influence on most of these parameters in mice expressing human E3 (Table 1).

E4 and ApoE-/- mice displayed impaired cognitive performance when subjected to dietary challenge, while other genotypes were apparently unaffected. Notably, a prior study demonstrated subtle impairment in cognitive performance of E3 mice. While most E3 mice displayed superior cognitive performance in most parameters as compared to E4 mice, female E3 mice did not improve during training in spatial learning performance, while E4, ApoE-/-, and ApoE+/+ mice improved [56]. In addition, E3 males made more errors in a Y-maze-based active avoidance task [56]. The par- 
ticular tests used may reveal differentially-susceptible aspects of cognition. E3 mice subjected to dietary challenge displayed an increase in aggression at a level similar to that of E4 mice, while -/- mice did not display any increase (Table 1). This differential impact is consistent with prior studies indicating that cognitive performance can be improved in rodents independently of aggression [57,58]. Similarly, while both cognitive impairment and aggression accompany $\mathrm{AD}$, they are not necessarily temporally colocalized and may but do not necessarily respond to identical treatments [59-62]. These behavioral manifestations in mice are directly relevant since $\mathrm{AD}$ can be accompanied by psychosis and agitation [63], and ApoE4 can also potentiate psychotic symptoms in humans [64]. These findings suggest that aggression, but not cognition, may be one instance in which the presence of the E4 (and E3) genotype, rather than the absence of ApoE function (i.e., ApoE-/- mice) may be the contributing factor [65].

Classical biochemical markers were also affected by dietary challenge. When subjected to dietary challenge, E3 mice displayed increases in oxidative damage, PS-1 expression, and $\gamma$-secretase activity identical to those of E4 mice (Table 1). However, neither A $\beta$ nor phosphotau levels were increased in E3 mice. Genotypic deficiencies were evident in certain of these biochemical parameters prior to dietary challenge. For example, both E3 and E4 but not E2 mice displayed identical increases $(1.4 \pm 0.1)$ in PS- 1 expression and $\gamma$-secretase activity on the complete diet as they did on the deficient diet [52]. Oxidative damage was elevated in E4 and ApoE-/- mice, but not in E3 or ApoE+/+ mice, when maintained on the complete diet. The only alteration in these parameters when ApoE $+/+$ were placed on the challenge diet was in PS-1; ApoE+/+ mice showed a 1.7 \pm 0.1 -fold increase when maintained on the challenge diet [66]. However, the combination of genotype and dietary challenge clearly potentiated these behavioral and biochemical parameters (Table 1).

These comparisons are not intended to suggest that E3 is as detrimental as E4, but are intended to highlight that the protective properties of E3 may be diminished under dietary challenge. Numerous studies of parameters not examined herein clearly demonstrate that E3 provides superior neuroprotection than does E4 [35]. For example, E3 mice display increased dendritic spine density as compared to E4 [67]. The presence of the $\mathrm{E} 3$ allele also exerts a dose-dependent reduction in $\mathrm{A} \beta$ deposition [66], and a decrease in $\gamma$-secretase-mediated $\mathrm{A} \beta$ generation [25]. These latter findings perhaps explain why E3 mice under dietary challenge did not display increased A $\beta$ levels despite increases in PS- 1 and $\gamma$-secretase activity (Table 1) [52].

\section{HYPOTHETICAL RELATIONSHIP OF E3 AND AD}

Could the above findings regarding E3 in mouse models subjected to dietary compromise have significance for $\mathrm{AD}$ ? The vast majority (73\%) of the population does not harbor an E4 allele, yet still account for $50 \%$ of the cases of AD [5]. Moreover, in tallying cases and relative impact of alleles, investigators typically compare the prevalence of $\mathrm{AD}$ in individuals bearing one or more E4 alleles versus those lacking E4 and bearing one or more E3 alleles. This approach is often required to obtain sufficient numbers for statistical analyses, as E3 is the major allele, and only approximately $2 \%$ of the population harbors the E4/4 genotype. The unfortunate downside of grouping individuals homozygous and heterozygous for E4 precludes comparison of the E3/4 and E4/4 genotype.

Prior reviews of data from multi-center studies indicate that individuals with E3/4 were approximately $70 \%$ less likely to present AD than were those with E4/4; however, individuals with E2/4 were approximately $90 \%$ less likely to present AD. While such data are usually presented in the context that E2 and E3 reduce or nullify the impact of a single E4 allele, they also underscore the substantially greater neuroprotective effect of E2 versus E3 [69-71]. The percentage of individuals with $\mathrm{AD}$ that are homozygous for E3 slightly exceeded that with E2/4 (5.0\% vs. $4.5 \%)$ in one of the above studies [71], and rivaled that with E2/4 in the second study (5.2 versus 8.7) [71]. These data indicate that E2 can nullify the impact of a single E4 allele. However, they also suggest that individuals harboring the E3/3 genotype may be equally at risk for $\mathrm{AD}$ as are individuals with the E2/4 genotype. Despite that any putative impact of $\mathrm{E} 3$ as a risk factor for $\mathrm{AD}$ is dwarfed in comparison to that of E4, a virtually linear relationship exists in the percentage of individuals with $\mathrm{AD}$ and the number of E3 versus E2 alleles and in the lifetime risk of AD (Fig. 1).

\section{NUTRITIONAL DEFICIENCY MAY POTENTIATE THE IMPACT OF APOE GENOTYPE ON AD}

AD has a multifactoral etiology encompassing genetic, nutritional, and environmental risk factors. No one class of risk factors can account for the full incidence of $\mathrm{AD}[3,36,73]$. Clinical manifestation may therefore be dependent upon convergence of two or more risk 

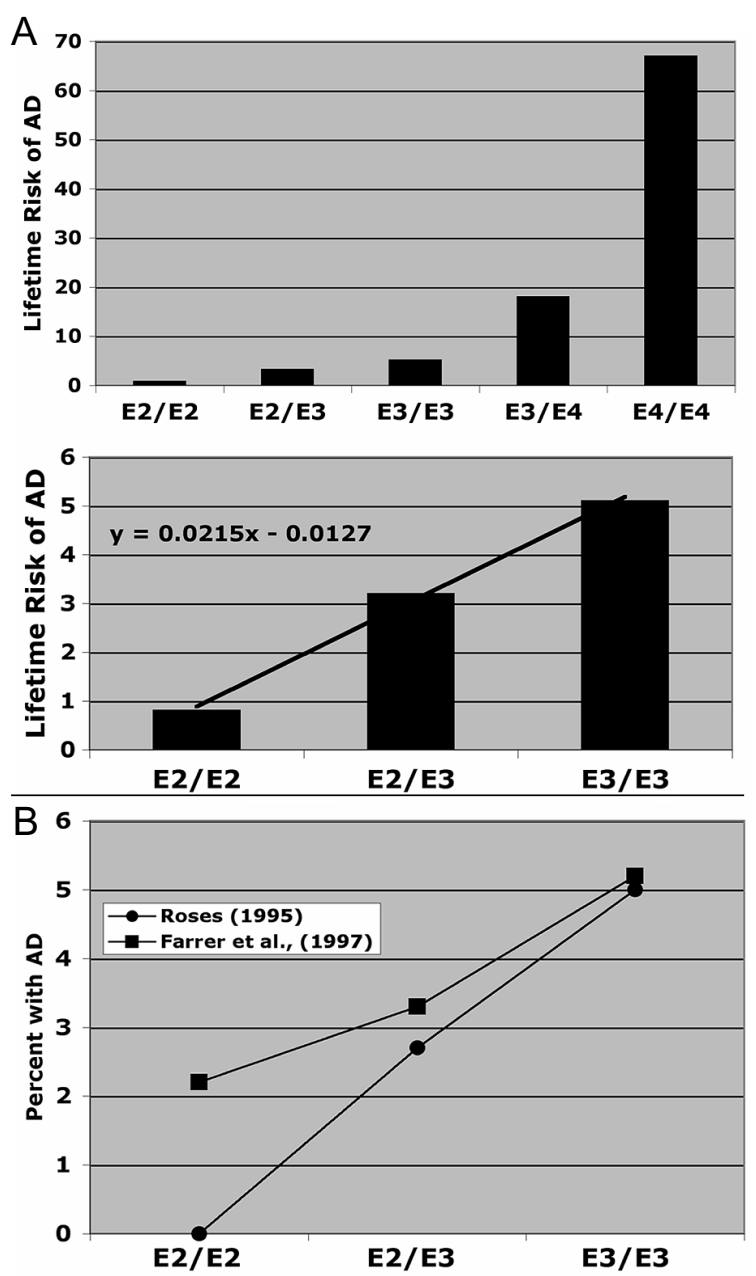

Fig. 1. Differential impact of E2 and E3 on prevalence of AD. Panel A presents the lifetime risk of AD for various ApoE genotypes. The upper graph includes genotypes with $\mathrm{E} 4$, while the lower graph excludes E4. Note that, while the potential contribution of other alleles to a lifetime risk of $\mathrm{AD}$ is minimal compared to that of $\mathrm{E} 4$, the genotypes of E2/2, E2/3, and E3/3 present a linear increase in the lifetime risk of AD. Data from [5]. Panel B presents data from two meta-studies as indicated which demonstrate that a virtually linear relationship exists in the percentage of individuals with $\mathrm{AD}$ and the number of E3 versus E2 alleles.

factors, and such has been suggested for the impact of ApoE on $\mathrm{AD}$ [74]. In this regard, even the E4/4 genotype is not a predictor in isolation; the fact that E4 exhibits an incomplete penetrance (60\% [2];) suggests the need for one or more additional contributing factors (else would not E4/4 exhibit $100 \%$ penetrance?). The findings reviewed herein demonstrate that key nutritional compromise, including that of folate, may be one of these additional risk factors [75]. Genetic deficiencies in folate usage may also represent a contributing factor even in the presence of otherwise sufficient dietary intake. For example, the C677T polymorphism of 5',10' methylene tetrahydrofolate reductase (which utilizes folate to regenerate methionine from homocysteine) is an ApoE4-dependent AD risk factor [76-79]. Transgenic mice expressing this polymorphism were more severely compromised in the above behavioral and biochemical parameters than were wild-type mice when each were maintained on the challenge diet [78]. Detailed studies in humans are wanting, although vitamin E-induced neuroprotection was compromised in AD patients with E4 [80]. Genetic predispositions placing an individual at risk for age-related disorders including $\mathrm{AD}$ may remain latent pending age-related decline in nutrition and/or homeostasis [45-49].

Rather than simply considering E4 to be detrimental and E2 and E3 to be beneficial, the differential impact of ApoE alleles represents a continuum, with E4 the most detrimental and E2 the most beneficial [22, 70]. Retrospective epidemiological analyses as presented above indicate that E3 is capable of contributing to $\mathrm{AD}$, especially in concert with other deleterious influences such as nutritional compromise. The transgenic mouse studies reviewed herein demonstrate not only that dietary oxidative challenge can potentiate the risk associated with $\mathrm{E} 4$, but also suggest that it can in some cases exert a similar deleterious interaction with E3. While murine model data can at best only be extrapolated to the human condition, they are nevertheless consistent with the early contribution of oxidative stress to AD [11], the ability for E4 to account for only $50 \%$ of the cases of $\mathrm{AD}$, and the linear relationship of $\mathrm{E} 3$ versus $\mathrm{E} 2$ for risk of $\mathrm{AD}[71,73]$. Extrapolation of these findings in mice to the human condition, coupled with the experimental data presented herein, lead us to hypothesize that the E3 allele may not provide sufficient neuroprotection under conditions of dietary compromise and/or oxidative challenge. Notably, this article has not addressed additional deleterious effects associated with ApoE metabolism, which may also indirectly impact cognition [81]. Lifestyle approaches suggested to counter the recognized "at-risk" E4 genotype [13, 75,82-85] should therefore perhaps not be ignored by individuals bearing the other alleles.

\section{DISCLOSURE STATEMENTS}

Authors' disclosures available online (http://www.jalz.com/disclosures/view.php?id=346). 


\section{REFERENCES}

[1] Corder EH, Saunders AM, Strittmatter WJ, Schmechel DE, Gaskell PC, Small GW, Roses AD, Haines JL, Pericak-Vance MA (1993) Gene dose of apolipoprotein E type 4 allele and the risk of Alzheimer's disease in late onset families. Science 261, 921-923.

[2] Growdon JH (2001) Incorporating biomarkers into clinical drug trials in Alzheimer's disease. J Alzheimers Dis 3, 287 292.

[3] Kamboh MI (2004) Molecular genetics of late-onset Alzheimer's disease. Ann Hum Genet 68, 381-404.

[4] Rebeck GW, Kindy M, LaDu MJ (2002) Apolipoprotein E and Alzheimer's disease: the protective effects of ApoE2 and E3. J Alzheimers Dis 4, 145-154.

[5] Raber J, Huang Y, Ashford JW (2004) ApoE genotype accounts for the vast majority of $\mathrm{AD}$ risk and $\mathrm{AD}$ pathology. Neurobiol Aging 25, 641-650.

[6] Cedazo-Minguez A (2007) Apolipoprotein E and Alzheimer's disease: molecular mechanisms and therapeutic opportunities. J Cell Mol Med 11, 1227-1238.

[7] Barger SW, Harmon AD (1997) Microglial activation by Alzheimer amyloid precursor protein and modulation by apolipoprotein E. Nature 388, 878-881.

[8] Berr C (2002) Oxidative stress and cognitive impairment in the elderly. J Nutr Health Aging 6, 261-266.

[9] Chen Y, Lomnitski L, Michaelson DM, Shohami E (1997) Motor and cognitive deficits in apolipoprotein E-deficient mice after closed head injury. Neuroscience 80, 1255-1262.

[10] Hu J, LaDu MJ, Van Eldik LJ (1998) Apolipoprotein E attenuates beta-amyloid-induced astrocyte activation. J Neurochem 71, 1626-1634.

[11] Perry G, Cash AD, Smith MA (2002) Alzheimer disease and oxidative stress. J Biomed Biotechnol 2, 120-123.

[12] Perry G, Nunomura A, Hirai K, Zhu X, Perez M, Avila J, Castellani RJ, Atwood CS, Aliev G, Sayre LM, Takeda A, Smith MA (2002) Is oxidative damage the fundamental pathogenic mechanism of Alzheimer's and other neurodegenerative diseases? Free Radic Biol Med 33, 1475-1479.

[13] Jofre-Monseny L, Minihane AM, Rimbach G (2008) Impact of apoE genotype on oxidative stress, inflammation and disease risk. Mol Nutr Food Res 52, 131-145.

[14] Ramassamy C, Averill D, Beffert U, Bastianetto S, Theroux L, Lussier-Cacan S, Cohn JS, Christen Y, Davignon J, Quirion R, Poirier J (1999) Oxidative damage and protection by antioxidants in the frontal cortex of Alzheimer's disease is related to the apolipoprotein E genotype. Free Radic Biol Med 27, 544-553.

[15] Ramassamy C, Averill D, Beffert U, Theroux L, Lussier-Cacan S, Cohn JS, Christen Y, Schoofs A, Davignon J, Poirier J (2000) Oxidative insults are associated with apolipoprotein E genotype in Alzheimer's disease brain. Neurobiol Dis 7, 23-37.

[16] Ramassamy C, Krzywkowski P, Averill D, Lussier-Cacan S, Theroux L, Christen Y, Davignon J, Poirier J (2001) Impact of apoE deficiency on oxidative insults and antioxidant levels in the brain. Brain Res Mol Brain Res 86, 76-83.

[17] Ferrer I, Gomez-Isla T, Puig B, Freixes M, Ribe E, Dalfo E, Avila J (2005) Current advances on different kinases involved in tau phosphorylation, and implications in Alzheimer's disease and tauopathies. Curr Alzheimer Res 2, 3-18.

[18] LaFerla FM, Oddo S (2005) Alzheimer's disease: Abeta, tau and synaptic dysfunction. Trends Mol Med 11, 170-176.
[19] Pratico D, Rokach J, Tangirala RK (1999) Brains of aged apolipoprotein E-deficient mice have increased levels of F2isoprostanes, in vivo markers of lipid peroxidation. $\mathrm{J} \mathrm{Neu}$ rochem 73, 736-741.

[20] Sheng H, Laskowitz DT, Mackensen GB, Kudo M, Pearlstein RD, Warner DS (1999) Apolipoprotein E deficiency worsens outcome from global cerebral ischemia in the mouse. Stroke 30, 1118-1124.

[21] Kobayashi M, Ishiguro K, Katoh-Fukui Y, Yokoyama M, Fujita SC (2003) Phosphorylation state of tau in the hippocampus of apolipoprotein E4 and E3 knock-in mice. Neuroreport 14, 699-702.

[22] Ashford JW (2002) ApoE4: is it the absence of good or the presence of bad? J Alzheimers Dis 4, 141-143.

[23] Mosconi L, Nacmias B, Sorbi S, De Cristofaro MT, Fayazz M, Tedde A, Bracco L, Herholz K, Pupi A (2004) Brain metabolic decreases related to the dose of the ApoE e4 allele in Alzheimer's disease. J Neurol Neurosurg Psychiatry 75, 370-376.

[24] Zhong N, Ramaswamy G, Weisgraber KH. (2009) Apolipoprotein E4 domain interaction induces endoplasmic reticulum stress and impairs astrocyte function. $J$ Biol Chem 284, 27273-27280.

[25] Irizarry MC, Deng A, Lleo A, Berezovska O, Von Arnim CA, Martin-Rehrmann M, Manelli A, LaDu MJ, Hyman BT, Rebeck GW (2004) Apolipoprotein E modulates gammasecretase cleavage of the amyloid precursor protein. $\mathrm{J} \mathrm{Neu}$ rochem $\mathbf{9 0}, 1132-1143$.

[26] Pastor P, Roe CM, Villegas A, Bedoya G, Chakraverty S, Garcia G, Tirado V, Norton J, Rios S, Martinez M, Kosik KS, Lopera F, Goate AM (2003) Apolipoprotein Eepsilon4 modifies Alzheimer's disease onset in an E280A PS1 kindred. Ann Neurol 54, 163-169.

[27] Cam JA, Bu G (2006) Modulation of beta-amyloid precursor protein trafficking and processing by the low density lipoprotein receptor family. Mol Neurodegener 1, 8 .

[28] Fagan AM, Watson M, Parsadanian M, Bales KR, Paul SM, Holtzman DM (2002) Human and murine ApoE markedly alters A beta metabolism before and after plaque formation in a mouse model of Alzheimer's disease. Neurobiol Dis $\mathbf{9}$, 305-318.

[29] Hone E, Martins IJ, Fonte J, Martins RN (2003) Apolipoprotein $\mathrm{E}$ influences amyloid-beta clearance from the murine periphery. J Alzheimers Dis 5, 1-8.

[30] Manelli AM, Bulfinch LC, Sullivan PM, LaDu MJ (2007) Abeta42 neurotoxicity in primary co-cultures: effect of apoE isoform and Abeta conformation. Neurobiol Aging 28, 11391147.

[31] Trommer BL, Shah C, Yun SH, Gamkrelidze G, Pasternak ES, Stine WB, Manelli A, Sullivan P, Pasternak JF, LaDu MJ (2005) ApoE isoform-specific effects on LTP: blockade by oligomeric amyloid-beta1-42. Neurobiol Dis 18, 75-82.

[32] Xu F, Vitek MP, Colton CA, Previti ML, Gharkholonarehe N, Davis J, Van Nostrand WE (2008) Human apolipoprotein E redistributes fibrillar amyloid deposition in Tg-SwDI mice. $J$ Neurosci 28, 5312-5320.

[33] Butterfield DA, Lauderback CM (2002) Lipid peroxidation and protein oxidation in Alzheimer's disease brain: potential causes and consequences involving amyloid beta-peptideassociated free radical oxidative stress. Free Radic Biol Med 32, 1050-1060.

[34] Carter J, Lippa CF (2001) Beta-amyloid, neuronal death and Alzheimer's disease. Curr Mol Med 1, 733-737. 
[35] Huang GS, Yang SM, Hong MY, Yang PC, Liu YC (2000) Differential gene expression of livers from ApoE deficient mice. Life Sci 68, 19-28.

[36] Parihar MS, Hemnani T (2004) Alzheimer's disease pathogenesis and therapeutic interventions. J Clin Neurosci 11, 456467.

[37] Perry G, Nunomura A, Hirai K, Takeda A, Aliev G, Smith MA (2000) Oxidative damage in Alzheimer's disease: the metabolic dimension. Int J Dev Neurosci 18, 417-421.

[38] Shea TB, Rogers E, Ashline D, Ortiz D, Sheu MS (2002) Apolipoprotein E deficiency promotes increased oxidative stress and compensatory increases in antioxidants in brain tissue. Free Radic Biol Med 33, 1115-1120.

[39] Sung S, Yao Y, Uryu K, Yang H, Lee VM, Trojanowski JQ, Pratico D (2004) Early vitamin E supplementation in young but not aged mice reduces Abeta levels and amyloid deposition in a transgenic model of Alzheimer's disease. FASEB $J \mathbf{1 8}$, 323-325.

[40] Veinbergs I, Mallory M, Sagara Y, Masliah E (2000) Vitamin E supplementation prevents spatial learning deficits and dendritic alterations in aged apolipoprotein E-deficient mice. Eur J Neurosci 12, 4541-4546.

[41] Nunomura A, Moreira PI, Lee HG, Zhu X, Castellani RJ, Smith MA, Perry G. (2007) Neuronal death and survival under oxidative stress in Alzheimer and Parkinson diseases. CNS Neurol Disord Drug Targets. 6, 411-423.

[42] Mattson MP, Shea TB (2003) Folate and homocysteine metabolism in neural plasticity and neurodegenerative disorders. Trends Neurosci 26, 137-146.

[43] O’Donnell E, Lynch MA (1998) Dietary antioxidant supplementation reverses age-related neuronal changes. Neurobiol Aging 19, 461-467.

[44] Farrer LA, Cupples LA, Haines JL, Hyman B, Kukull WA, Mayeux R, Myers RH, Pericak-Vance MA, Risch N, van Duijn CM. (1997) Effects of age, sex, and ethnicity on the association between apolipoprotein E genotype and Alzheimer disease. A meta-analysis. APOE and Alzheimer Disease Meta Analysis Consortium. JAMA 278, 1349-1356.

[45] Bickeböller H, Campion D, Brice A, Amouyel P, Hannequin D, Didierjean O, Penet C, Martin C, Pérez-Tur J, Michon A, Dubois B, Ledoze F, Thomas-Anterion C, Pasquier F, Puel M, Demonet JF, Moreaud O, Babron MC, Meulien D, Guez D, Chartier-Harlin MC, Frebourg T, Agid Y, Martinez M, ClergetDarpoux F (1997) Apolipoprotein E and Alzheimer disease: genotype-specific risks by age and sex. Am J Hum Genet $\mathbf{1 6 0}$, 439-446.

[46] Warzok RW, Kessler C, Apel G, Schwarz A, Egensperger R, Schreiber D, Herbst EW, Wolf E, Walther R, Walker LC (1998) Apolipoprotein E4 promotes incipient Alzheimer pathology in the Elderly. Alzheimer Dis Assoc Disord 12, 33-39.

[47] Ho PI, Ashline D, Dhitavat S, Ortiz D, Collins SC, Shea TB, Rogers E (2003) Folate deprivation induces neurodegeneration: roles of oxidative stress and increased homocysteine. Neurobiol Dis 14, 32-42.

[48] Ho PI, Collins SC, Dhitavat S, Ortiz D, Ashline D, Rogers E, Shea TB (2001) Homocysteine potentiates beta-amyloid neurotoxicity: role of oxidative stress. J Neurochem 78, 249253.

[49] Ho PI, Ortiz D, Rogers E, Shea TB (2002) Multiple aspects of homocysteine neurotoxicity: glutamate excitotoxicity, kinase hyperactivation and DNA damage. J Neurosci Res 70, 694702 .

[50] White AR, Huang X, Jobling MF, Barrow CJ, Beyreuther K, Masters CL, Bush AI, Cappai R (2001) Homocysteine po- tentiates copper- and amyloid beta peptide-mediated toxicity in primary neuronal cultures: possible risk factors in the Alzheimer's-type neurodegenerative pathways. J Neurochem 76, $1509-1520$

[51] Chan A, Shea TB (2007) Folate deprivation increases presenilin expression, gamma-secretase activity, and Abeta levels in murine brain: potentiation by ApoE deficiency and alleviation by dietary S-adenosyl methionine. J Neurochem 102 753-760.

[52] Chan A, Tchantchou F, Rogers EJ, Shea TB (2009) Dietary deficiency increases presenilin expression, gamma-secretase activity, and Abeta levels: potentiation by ApoE genotype and alleviation by S-adenosyl methionine. J Neurochem $\mathbf{1 1 0}$, 831-836.

[53] Fuso A, Seminara L, Cavallaro RA, D'Anselmi F, Scarpa S (2005) S-adenosylmethionine/homocysteine cycle alterations modify DNA methylation status with consequent deregulation of PS1 and BACE and beta-amyloid production. Mol Cell Neurosci 28, 195-204.

[54] Scarpa S, Fuso A, D’Anselmi F, Cavallaro RA (2003) Presenilin 1 gene silencing by $S$-adenosylmethionine: a treatment for Alzheimer disease? FEBS Lett 541, 145-148.

[55] Tchantchou F, Graves M, Rogers E, Ortiz D, Shea TB (2005) $\mathrm{N}$-acteyl cysteine alleviates oxidative damage to central nervous system of ApoE-deficient mice following folate and vitamin E-deficiency. J Alzheimers Dis 7, 135-138; discussion 173-180.

[56] Grootendorst J, Bour A, Vogel E, Kelche C, Sullivan PM, Dodart JC, Bales K, Mathis C (2005) Human apoE targeted replacement mouse lines: h-apoE4 and h-apoE3 mice differ on spatial memory performance and avoidance behavior. Behav Brain Res 159, 1-14.

[57] Minkeviciene R, Banerjee P, Tanila H (2004) Memantine improves spatial learning in a transgenic mouse model of Alzheimer's disease. J Pharmacol Exp Ther 311, 677-682.

[58] Popovic M, Caballero-Bleda M, Popovic N, Bokonjic D, Dobric S (1997) Neuroprotective effect of chronic verapamil treatment on cognitive and noncognitive deficits in an experimental Alzheimer's disease in rats. Int J Neurosci 92, 79-93.

[59] Arsland D (1998) [Drug treatment of emotional and cognitive dysfunction in dementia]. Tidsskr Nor Laegeforen 118, 560565.

[60] Moran M, Walsh C, Lynch A, Coen RF, Coakley D, Lawlor BA (2004) Syndromes of behavioural and psychological symptoms in mild Alzheimer's disease. Int J Geriatr Psychiatry 19, 359-364.

[61] Rainer MK, Masching AJ, Ertl MG, Kraxberger E, Haushofer M (2001) Effect of risperidone on behavioral and psychological symptoms and cognitive function in dementia. $J$ Clin Psychiatry 62, 894-900.

[62] Russo-Neustadt A, Cotman CW (1997) Adrenergic receptors in Alzheimer's disease brain: selective increases in the cerebella of aggressive patients. J Neurosci 17, 5573-5580.

[63] Conn D, Thorpe L (2007) Assessment of behavioural and psychological symptoms associated with dementia. Can J Neurol Sci 34 Suppl 1, S67-71.

[64] Zdanys KF, Kleiman TG, MacAvoy MG, Black BT, Rightmer TE, Grey M, Garman KS, Tampi RR, Gelernter J, van Dyck CH (2007) Apolipoprotein E epsilon4 allele increases risk for psychotic symptoms in Alzheimer's disease. Neuropsychopharmacology 32, 171-179.

[65] Teter B, Raber J, Nathan B, Crutcher KA (2002) The presence of apoE4, not the absence of apoE3, contributes to AD pathology. J Alzheimers Dis 4, 155-163. 
[66] Chan AY, Alsaraby A, Shea TB (2008) Folate deprivation increases tau phosphorylation by homocysteine-induced calcium influx and by inhibition of phosphatase activity: Alleviation by S-adenosyl methionine. Brain Res 1199, 133-137.

[67] Ji Y, Gong Y, Gan W, Beach T, Holtzman DM, Wisniewski T (2003) Apolipoprotein E isoform-specific regulation of dendritic spine morphology in apolipoprotein E transgenic mice and Alzheimer's disease patients. Neuroscience 122, 305-315.

[68] DeMattos RB (2004) Apolipoprotein E dose-dependent modulation of beta-amyloid deposition in a transgenic mouse model of Alzheimer's disease. J Mol Neurosci 23, 255-262.

[69] Ashford JW (2004) APOE genotype effects on Alzheimer's disease onset and epidemiology. J Mol Neurosci 23, 157-165.

[70] Crutcher KA (2004) Apolipoprotein E is a prime suspect, not just an accomplice, in Alzheimer's disease. J Mol Neurosci 23, 181-188.

[71] Roses AD (1995) Apolipoprotein E genotyping in the differential diagnosis, not prediction, of Alzheimer's disease. Ann Neurol 38, 6-14.

[72] Farrer LA, Cupples LA, Haines JL, Hyman B, Kukull WA, Mayeux R, Myers RH, Pericak-Vance MA, Risch N, van Duijn CM (1997) Effects of age, sex, and ethnicity on the association between apolipoprotein E genotype and Alzheimer disease. A meta-analysis. APOE and Alzheimer Disease Meta Analysis Consortium. JAMA 278, 1349-1356.

[73] Grant WB, Campbell A, Itzhaki RF, Savory J (2002) The significance of environmental factors in the etiology of Alzheimer's disease. J Alzheimers Dis 4, 179-189.

[74] Lahiri DK, Sambamurti K and Bennett DA (2004) Apolipoprotein gene and its interaction with the environmentally driven risk factors: molecular, genetic and epidemiological studies of Alzheimer's disease. Neurobiol Aging 5, 651-660.

[75] Shea TB, Chan A (2008) S-adenosyl methionine: a natural therapeutic agent effective against multiple hallmarks and risk factors associated with Alzheimer's disease. J Alzheimers Dis 13, 67-70.

[76] Anello G, Gueant-Rodriguez RM, Bosco P, Gueant JL, Romano A, Namour B, Spada R, Caraci F, Pourie G, Daval JL, Ferri R (2004) Homocysteine and methylenetetrahydrofolate reductase polymorphism in Alzheimer's disease. Neuroreport 15, 859-861.

[77] Regland B, Blennow K, Germgard T, Koch-Schmidt AC,
Gottfries CG (1999) The role of the polymorphic genes apolipoprotein E and methylene - tetrahydrofolate reductase in the development of dementia of the Alzheimer type. Dement Geriatr Cogn Disord 10, 245-251.

[78] Wang B, Jin F, Kan R, Ji S, Zhang C, Lu Z, Zheng C, Yang Z, Wang L (2005) Association of MTHFR gene polymorphism C677T with susceptibility to late-onset Alzheimer's disease. $J$ Mol Neurosci 27, 23-27.

[79] Chan A, Tchantchou F, Graves V, Rozen R, Shea TB (2008) Dietary and genetic compromise in folate availability reduces acetylcholine, cognitive performance and increases aggression: critical role of S-adenosyl methionine. J Nutr Health Aging 12, 252-261.

[80] Mas E, Dupuy AM, Artero S, Portet F, Cristol JP, Ritchie K and Touchon (2006) Functional vitamin E deficiency in ApoE4 patients with Alzheimer's disease Dem Geriatr Cogn Disord 21, 198-204

[81] Beeri MS, Ranova-Springer R, Silverman JM, Haroutunian V (2009) The effects of cardiovascular risk factors on cognitive compromise. Dialog Clin Neurosci 11, 201-212.

[82] Ashford JW, Mortimer JA (2002) Non-familial Alzheimer's disease is mainly due to genetic factors. J Alzheimers Dis $\mathbf{4}$, 169-177.

[83] Shea TB, Chan A (2006) Food for thought: Dietary influence on acetylcholine. J Alzheimers Dis 10, 363-364.

[84] Patterson C, Feightner JW, Garcia A, Hsiung GY, MacKnight C and Sadovnick AD (2008) Diagnosis and treatment of dementia: 1. Risk assessment and primary prevention of Alzheimer disease. CMAJ 178, 548-556.

[85] Lee Y, Back JH, Kim J, Kim SH, Na DL, Cheong HK, Hong $\mathrm{CH}$ and Kim YG (2010) Systematic review of health behavioral risks and cognitive health in older adults Int Psychogeriatr 22, 174-187.

[86] Chan A, Shea TB (2006) Dietary and genetically-induced oxidative stress alter tau phosphorylation: influence of folate and apolipoprotein E deficiency. J Alzheimers Dis 9, 399-405.

[87] Chan A, Shea TB (2007) Effects of dietary supplementation with $\mathrm{N}$-acetyl cysteine, acetyl-L-carnitine and S-adenosyl methionine on cognitive performance and aggression in normal mice and mice expressing human ApoE4. Neuromolecular Med 9, 264-269. 